\title{
Using the mineral component of building refuse in heavy metals sorption from their mixture
}

\author{
V.M. Yurk ${ }^{\mathrm{ab}}$, O.B. Zaytsev ${ }^{\mathrm{b}}$, A.V. Zaytseva ${ }^{\mathrm{b}}$, N.A. Malahova ${ }^{\mathrm{a}}$ \\ a: Ural Federal University named after the first President of Russia B.N. Yeltsin, \\ Institute of Chemical Engineering, 620002, 19 Mira st., Ekaterinburg, Russia \\ b: Ecology development of business (Ekologiia Razvitiia Biznesa (ERBi LLC)), \\ 620144, 195 Moskovskaya st., Ekaterinburg, Russia \\ * Corresponding author: v.yurk@yandex.ru
}

This short communication (letter) belongs to the MOSM2O20 Special Issue.

(C) 2021, The Authors. This article is published in open access form under the terms and conditions of the Creative Commons Attribution (CC BY) license (http://creativecommons.org/licenses/by/4.0/).
Abstract
The sorption properties of the sand-breakstone mixture based on the mineral component of building refuse of the $0-10 \mathrm{~mm}$ fraction with respect to $\mathrm{Pb}^{2+}, \mathrm{Zn}^{2+}, \mathrm{Cu}^{2+}, \mathrm{Ni}^{2+}, \mathrm{Cd}^{2+}$ and $\mathrm{Hg}^{2+}$ ions were studied us- ing atomic absorption spectroscopy. The mechanisms of accumula- tion of heavy metal ions on the surface of the mixture particles are described. It was found that after washing the contaminated material distilled water, the residual concentration of metals in the filtrate does not exceed the established sanitary and hygienic standards. The practical value of the work lies in the possibility of applying the re- sults in reclamation of technogenic formations or production of ma- terials for the technical stage of reclamation using technogenic soils.

\section{Keywords \\ contamination \\ heavy metal building refuse soil pollution}

Received: 03.11.2020

Revised: 25.12.2020

Accepted: 25.12.2020

Available online: 16.04 .2021

\section{Introduction}

The heavy metal pollution of the environment is a serious problem nowadays. Soils nearby to plant facilities and industrial dumping sites are the most intensively affected by this type of exposure. The forming of geochemical barriers is a prospective way to prevent heavy metal migration in polluted soils and to protect ground water. In accordance with contemporary conceptions a geochemical barrier is an open, non-equilibrium, dynamic and selforganizing system with a quantity of factors conditioning a contaminant fixation [1,2]. Thus, the investigation, description and modelling of geochemical barriers is really important.

Various materials are used to create artificial geochemical barriers. A choice of its components depends on pollutant properties and economic feasibility. At present, mining waste [3], organoclay [4], farm waste $[5,6]$ have been proposed as basic materials for artificial geochemical barriers. However, the use of mineral part of the building refuse for that is of interest of soils tilling from heavy metals. The ability of building refuse to sorb heavy metal ions has been proved by a lot of studies. Such barriers belong to physicochemical ones because ions fixation generally arises from coordination bond formation between metals and functional groups of barrier particles surface. Also, it was reported [7] that basic properties of building refuse which cause a high receptivity are capillary pores and silicon and calcium minerals in the composition.

The adsorption capacity of calcium-containing materials (concrete, foam concrete or brickbats) under dynamic conditions reaches $2.3 \mathrm{mg} / \mathrm{g}$ [8]. Recent studies have shown that the dynamic capacity of building refuse is comparable to the capacity of most synthetic sorbents $[9,10]$. So, this type of waste is more attractive for geochemical barriers formation because of abundance and availability at low cost. Also, calcium-containing materials have an alkaline reaction in water solution; therefore they can be used for soils disoxidation or neutralization of acidic tails. For example, calcium aluminate cement is good for reliable encapsulation and effective sorption of $\mathrm{Pb}^{2+}, \mathrm{Zn}^{2+}$ and $\mathrm{Cu}^{2+}$ [11] and $\mathrm{Cd}^{2+}, \mathrm{Mn}^{2+}, \mathrm{Ni}^{2+}, \mathrm{Fe}^{2+}, \mathrm{Cr}^{2+}$ [12]. Concrete has great geoecoprotective properties for protection of soil from radionuclides [13] and sulfide-rich tailings [3]. In [14], a concrete geoprotective embankment along the railroads to prevent contamination of adjacent soils with iron was proposed, and the paper [9] presents the recommendation to use of shungite-containing crushed stone waste for these purposes. The authors of $[15,16]$ developed a model of a multilayer geochemical barrier based on flask, clay, and kaolin accumulating $\mathrm{Hg}, \mathrm{Pb}, \mathrm{Fe}$, and $\mathrm{Cs}$ ions, as well as $\mathrm{Zn}, \mathrm{Cd}$, and $\mathrm{Cu}$.

Thus, the analysis of the literature data allows us to conclude that the use of building refuse as a raw material 
for the production of a geochemical barrier to the migration of heavy metal ions is promising. However, most of the adsorption studies have considered fixation of only one type of metal ions at once. Actually, one has to deal with media containing more than one pollutant. The available information does not allow to estimate the geoprotective potential of the building refuse in multicomponent systems, which soils are. The results of our statistical study of soil contamination in the Sverdlovsk region of Russian Federation [17] showed that four-five metals can be observed in contaminated soil at the same time. The present work belongs to the series of our studies on the development of a geochemical barrier based on building refuse for the reclaiming of industrial lands. The article presents the results of sorption studies of heavy metal ions from their mixture.

\section{Experimental}

\subsection{Materials}

The building refuse used in this study was composed of cement, concrete, firebrick, sand, hardened building mortar and other building materials. Cement and concrete composed a big part of this mixture. Before we examined this building refuse, it had been prepared at first. Utilizable components such as metal and wood ones were removed. After that, it was ground on a crusher. The basis of the derived sand-breakstone compound was a sand fraction with a particle size of up to $10 \mathrm{~mm}$, the grain-size composition of which are shown in Fig. 1.

\subsection{Sorption batch experiment}

The model solutions contained ions of heavy metals: lead, cadmium, zinc, copper, mercury and nickel. Sorption of heavy metals from their nitrate solution was studied in static conditions. A $30 \mathrm{~g}$ of sand-breakstone mixture was put into a $250 \mathrm{ml}$ cylindrical glass funnel and filled up by $30 \mathrm{ml}$ of a model solution. This suspension was kept for seven days at $25{ }^{\circ} \mathrm{C}$. After that the supernatant was filtered to analyze metal ions concentration. To determine

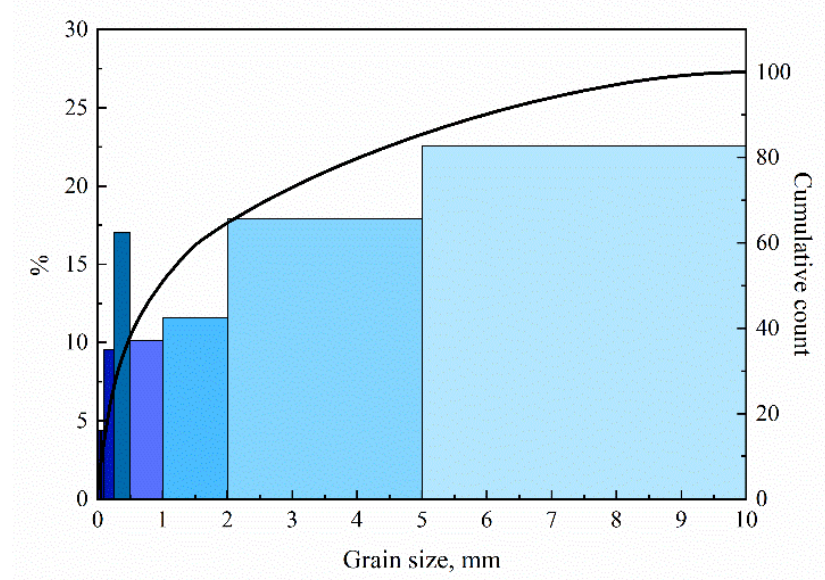

Fig. 1 The grain-size composition of sand-breakstone compound based on building refuse residual metals $(\mathrm{Pb}, \mathrm{Zn}, \mathrm{Cu}, \mathrm{Ni}, \mathrm{Hg}$ and $\mathrm{Cd})$ concentrations, the atomic absorption spectrometry (AAS) was used.

For determination of capability of sand-breakstone mixture to hold fixed metal ions on a surface of its particles, the batch experiment was carried out in dynamic conditions. Distilled water was leaked through a layer of building refuse mixture saturated by heavy metals. Eluates were collected at every $100 \mathrm{ml}$ and the residual metals concentrations were determined by AAS (AA-700o, Shimadzu, Japan).

\section{Results and Discussion}

The laboratory studies of the sorption properties of the sand-gravel mixture were carried out in an aqueous medium. This approach allows us to evaluate the full adsorption capacity of the material and its geoprotective properties. Moreover, moisture is always present in the soil and the migration of heavy metal ions occurs with its active participation. Therefore, the obtained data can be successfully adapted for use in soils.

Determining the initial concentration of metals in model solutions, we used the statistical data on soil pollution obtained by analyzing the ecological engineering surveys of capital construction objects in which ERBi LLC took part for 2015-2018. The sampling was carried out mainly on sites in Yekaterinburg and the Sverdlovsk region and included soils with the "extremely dangerous" category of pollution. These soils must not be used in any way and have to be neutralized.

The model solution of the experiment 1 contained a concentration of metal ions, which corresponds to their maximum content in contaminated soils of the "extremely dangerous" category, discovered during engineering surveys of various sites for construction projects in Yekaterinburg.

One should bear in mind that soils in industrial areas can be exposed to increased anthropogenic pollution, as a result of which the heavy metals concentrations in them can exceed the values being detected during engineering surveys. Such soils are also classified as "extremely dangerous" and must be utilized. The ability of a sandbreakstone mixture to exhibit geoprotective properties under these conditions were estimated in the experiment 2.

Also, as a result of various emergency situations, spills of reagents containing metal compounds on the soil may occur, contributing to their extreme pollution. Material properties in the conditions of emergency soil contamination were evaluated during the experiment 3.

The initial data on the metals concentrations in model solutions in accordance with the situations described above are presented in Table 1.

The ability of sand-breakstone mixture to sorb heavy metals was assessed in aqueous solutions because due to the dissolution processes, the ability to migrate to lower 
layers of the soil and further to aquifers increases in moisture medium. So, the most unfavorable environmental conditions for each of the considering situations were simulated, since in the experiments all metals are in their most mobile form, while under natural conditions the proportion of the mobile form of metals is far from $100 \%$ of the total content.

The results of the sorption of heavy metals by the studied building refuse mixture modeling various levels of environmental pollution are shown in Table 2.

The experimental results demonstrate a high sorption activity of building refuse to all heavy metal ions presented in the model solutions. The sorption efficiency for each element in all experiments exceeds 99\%. The adsorption capacity of cadmium is better because a minimal concentration of it in the filtrate is observed.

The decrease in the residual concentration of metals in the filtrate with an increase in their concentration in the model solution has been noticed. This phenomenon can be explained by the alkaline reaction of an aqueous solution and leaching of calcium ions into the solution. As a result of calcium hydrolysis, $\mathrm{Ca}(\mathrm{OH})_{2}$ particles are formed in solution. Also, hydrolysis of metal salts occurs in the alkaline medium and a sol of the corresponding hydroxides is formed. The growth of the metals concentrations in the model solution increases the amount of hydrosol in the solution. Joining to the particles of the material, it provides additional fixation of free metal ions from the solution that increases the purification efficiency of the process. In addition, $\mathrm{Ca}(\mathrm{OH})_{2}$ and $\mathrm{CaO}$ particles act as links which are capable to sorb metal hydroxide molecules on its surface and to agglomerate it. An indirect confirmation of the implementation of such mechanisms is the formation of a loose precipitate over the surface of the studied material, observed throughout the process.

The metal hydroxides formation in soils and their transition from a mobile to a fixed form (hydroxide formation) begins at $\mathrm{pH}>5.5$ for lead and $>7.5$ for other metals [18]. The $\mathrm{pH}$ value in the filtrates after the sorption process in all experiments was 11.5-12.o. Therefore, most of the contaminants were in the $\mathrm{MeOH}_{\mathrm{n}}$ form after sorption. The mechanisms of metals interaction with the surface of the sorbent particles leading to their accumulation can be represented by the following reactions:

$$
\begin{aligned}
3 \mathrm{CaO} \cdot \mathrm{SiO}_{2}+2 \mathrm{H}_{2} \mathrm{O}+\mathrm{Me}^{2+} & \rightarrow \\
& \rightarrow \mathrm{MeO} \cdot \mathrm{SiO}_{2}+2 \mathrm{Me}(\mathrm{OH})_{\mathrm{n}}+\mathrm{Ca}^{2+} \\
\mathrm{CaO} \cdot \mathrm{SiO}_{2} \cdot \mathrm{H}_{2} \mathrm{O}+\mathrm{Me}^{\mathrm{n}+}+ & \mathrm{H}_{2} \mathrm{O} \rightarrow \\
\rightarrow & \rightarrow \mathrm{Me}(\mathrm{OH})_{\mathrm{n}}+\mathrm{SiO}_{2} \cdot \mathrm{H}_{2} \mathrm{O}+\mathrm{Ca}^{2+} \\
\mathrm{CaO} \cdot \mathrm{SiO}_{2} \cdot \mathrm{H}_{2} \mathrm{O}+\mathrm{Me}^{2+} \rightarrow & \mathrm{MeO} \cdot \mathrm{SiO}_{2} \cdot \mathrm{H}_{2} \mathrm{O}+\mathrm{Ca}^{2+}
\end{aligned}
$$

$$
\begin{aligned}
& 2 \mathrm{CaO} \cdot \mathrm{SiO}_{2} \cdot \mathrm{H}_{2} \mathrm{O}+\mathrm{Me}^{2+}+\mathrm{H}_{2} \mathrm{O} \rightarrow \\
& \quad \rightarrow \mathrm{MeO} \cdot \mathrm{SiO}_{2} \cdot \mathrm{H}_{2} \mathrm{O}+\mathrm{Ca}(\mathrm{OH})_{2}+\mathrm{Ca}^{2+} \\
& \begin{aligned}
& 2\left(2 \mathrm{CaO} \cdot \mathrm{SiO}_{2} \cdot \mathrm{H}_{2} \mathrm{O}\right)+ 3 \mathrm{Me}^{2+}+2 \mathrm{H}_{2} \mathrm{O} \rightarrow \\
& \rightarrow \mathrm{MeO} \cdot \mathrm{SiO}_{2} \cdot \mathrm{H}_{2} \mathrm{O}+\mathrm{CaO} \cdot \mathrm{SiO}_{2} \cdot \mathrm{H}_{2} \mathrm{O}+2 \mathrm{Me}(\mathrm{OH})_{\mathrm{n}}+3 \mathrm{Ca}^{2+} \\
& 3 \mathrm{CaO} \cdot \mathrm{SiO}_{2}+2 \mathrm{H}_{2} \mathrm{O} \rightarrow 2 \mathrm{CaO} \cdot \mathrm{SiO}_{2} \cdot \mathrm{H}_{2} \mathrm{O}+\mathrm{Ca}(\mathrm{OH})_{2}
\end{aligned}
\end{aligned}
$$

The mechanisms of heavy metals sorption demonstrate how the geochemical barrier based on the building refuse acts to prevent the migration of pollutants into deeper soils layers. However, it is necessary to bear in mind that soils are dynamic systems there are the processes of substance migration, such as aqueous solutions of organic components and inorganic compounds, continuously occur. Water influences the migration of many elements and since the sorption of metal ions on the surface of silicon, calcium and magnesium-containing materials is a reversible process, $\left(\mathrm{Me}^{\mathrm{n}+}\right)_{\text {sol }} \leftrightarrow\left(\mathrm{Me}^{\mathrm{n}+}\right)_{\text {sorb }}$, under corresponding conditions it washes out some of the ions being passed by the geochemical barrier.

So, experiments to determine the ability of a sandbreakstone mixture to retain heavy metal ions adsorbed on the surface of its particles in dynamic conditions were carried out. The results of the studies for each sample are shown in Fig. 2 as a dependence of the total content of metal ions in filtrates depending on the volume of water having passed through the sorbent layer. Fig. 3 shows similar relationships for each metal in the mixture. As can be seen from the presented data, a small part of the metals was washed out from the surface of the particles. The total

\begin{tabular}{|c|c|c|c|c|c|c|}
\hline \multirow{2}{*}{ Experiment № } & \multicolumn{6}{|c|}{ Metals concentrations, mg/l } \\
\hline & $\mathrm{Pb}$ & $\mathrm{Zn}$ & $\mathrm{Cd}$ & $\mathrm{Cu}$ & $\mathrm{Ni}$ & $\mathrm{Hg}$ \\
\hline 1 & 1888.17 & 1965.68 & 401.83 & 3773.37 & 3326.04 & 32.07 \\
\hline 2 & 2454.62 & $2555 \cdot 38$ & 522.38 & $4905 \cdot 38$ & 4323.85 & 41.69 \\
\hline 3 & 3191.00 & 3322.00 & 679.10 & 6377.00 & 5621.00 & 54.20 \\
\hline
\end{tabular}
metal content in the filtrate did not exceed $1 \mathrm{mg} / \mathrm{l}$, at that the highest concentration was typical for zinc, lead and mercury. The best resistance to leaching was possessed by cadmium ions, whose presence in the filtrate was practically not detected.

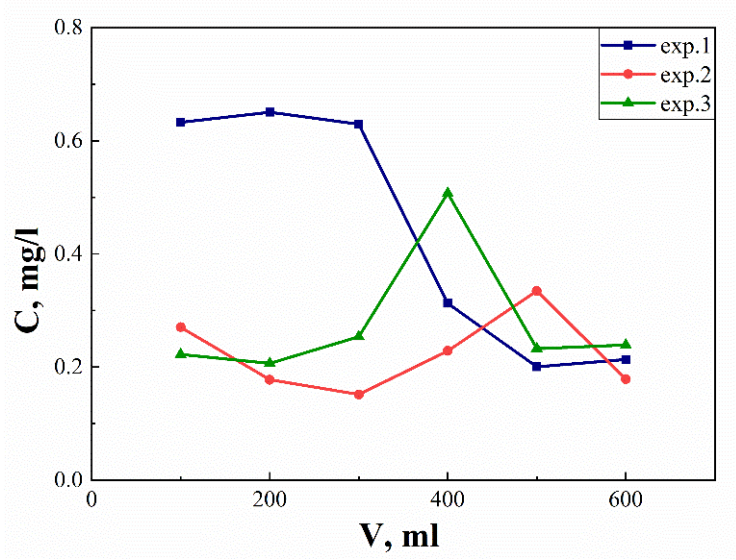

Fig. 2 The dynamics of leaching of sorbed metal ions (total) from contaminated material

Table 1 Initial concentrations of metal ions in model solutions 
Table 2 Residual concentrations of heavy metals in filtrate after sorption

\begin{tabular}{|c|c|c|c|c|c|c|}
\hline \multirow{2}{*}{ Experiment № } & \multicolumn{6}{|c|}{ Concentrations of metal ions in filtrate, $\mathrm{mg} / \mathrm{l}$} \\
\hline & $\mathrm{Pb}$ & $\mathrm{Zn}$ & $\mathrm{Cd}$ & $\mathrm{Cu}$ & $\mathrm{Ni}$ & $\mathrm{Hg}$ \\
\hline 1 & 0.57 & 0.165 & 0.0017 & 0.633 & 0.12 & 0.006 \\
\hline 2 & 0.08 & 0.138 & 0.0022 & 0.299 & 0.13 & 0.02 \\
\hline 3 & 0.05 & 0.041 & 0.0010 & 0.074 & 0.06 & 0.031 \\
\hline
\end{tabular}
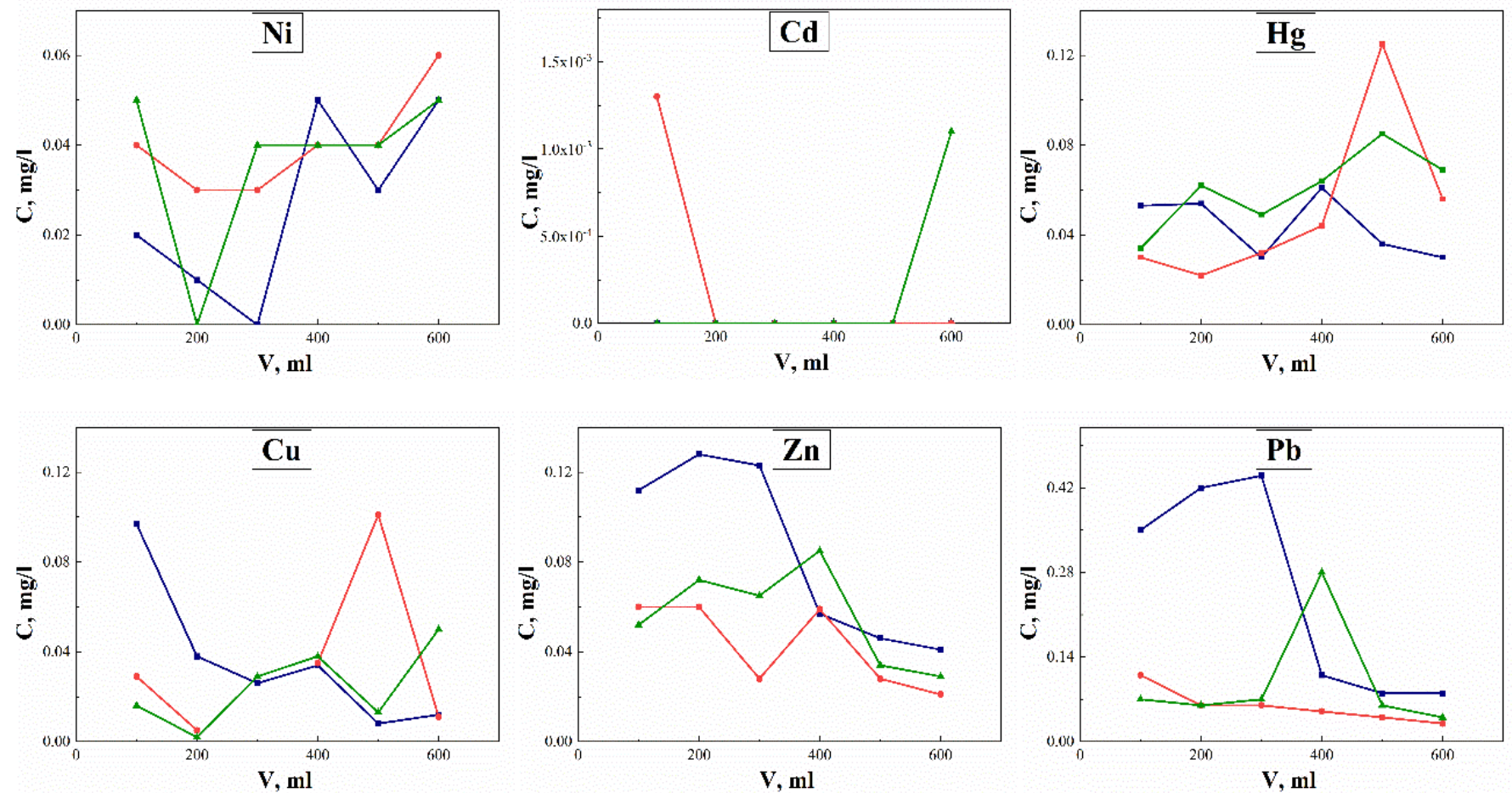

Fig. 3 The dynamics of leaching of each sorbed metal ions from contaminated material

It should be noted that there was no relationship between the initial concentration of metals in model solutions and the ability of particles of the sand-breakstone mixture to retain it. So, we can conclude that the strength of the adsorption depends on most of all the nature of the sorbent and the degree of affinity of elements to its surface, and to a lesser extent of concentration. It is known that sorption of $\mathrm{Cd}$ ions on the surface of calciumcontaining materials most often occurs by the mechanism of ion exchange [16], which increases the strength of their retention. The remaining metals can be bound by the mineral part of the building refuse through chemisorption and surface deposition. Such bond is less strong, since metals in hydrolyzed forms can change back to the mobile form when the external conditions of the process change.

Thus, part of the retained metals can enter the environment. Metals are washed out in a mobile form capable of the migration. Using the sand-breakstone mixture as a geochemical barrier, some of them will be accumulated by the organic matter of the soil. In order to assess the possible contamination of the underlying soils and the effectiveness of the barrier on the basis of the proposed sandbreakstone mixture, a comparison of the concentrations obtained with the sanitary and hygienic standards working in the Russian Federation was carried out. The maximum permissible concentration (MPC) values for acid soils were taken because of the most stringent values. A comparative analysis of the equilibrium concentrations of metals in the filtrates after washing the contaminated mixture with standard values MPC showed that their content did not exceed 0.01 part of MPC. Consequently, using the sand-breakstone mixture for reclamation of contaminated areas or mixed with contaminated soil will prevent the migration of pollutants to lower soils and underground horizons.

\section{Conclusions}

Thus, the present study shows the possibility of using the sand-breakstone mixture based on building refuse as geochemical barriers for the reclamation of technogenic formations, quarries, planning the territory. An analysis of the results showed a high sorption activity of the material to a mixture of heavy metals containing ions of lead, cadmium, nickel, zinc, copper and mercury both under static sorption conditions and in dynamic modeling conditions for soil filtration by surface runoff. The material studied in the work can be used during reclamation independently, or as a geochemical barrier preventing the migration of metal ions in a mixture with contaminated soil of the "extremely dangerous" category. 


\section{References}

1. Perel'man AI. Geochemical barriers: theory and practical applications. Applied Geochemistry. 1986;1(6):669-80. doi:10.1016/0883-2927(86)90088-0

2. Maximovich N, Khayrulina E. Artificial geochemical barriers for environmental improvement in a coal basin region. Environmental Earth Sciences. 2914;72:1915-24. doi:10.1007/s12665-014-3099-7

3. Bogush AA, Galkova OG, Ishuk NV. Geochemical barriers to elemental migration in sulfide-rich tailings: three case studies from Western Siberia. Mineralogical Magazine. 2012;76(7):2693-707. doi:10.1180/minmag.2012.076.7.05

4. Zhao Q, Choo H, Bhatt A, Burns SE, Bate B. Review of the fundamental geochemical and physical behaviors of organoclays in barrier applications. Applied Clay Science. 2017;142:2-20. doi:10.1016/j.clay.2016.11.024

5. Nguyena TAH, Ngoa HH, Guoa WS, Zhangb J, Liangb S, Yueb QY, Lib Q, Nguyen TV. Applicability of agricultural waste and by-products for adsorptive removal of heavy metals from wastewater. Bioresource Technology. 2013;148:574-85. doi:10.1016/j.biortech.2013.08.124

6. Kumar PS, Ramalingam S, Abhinaya RV, Kirupha SD, Murugesan A, Sivanesan S. Adsorption of metal ions onto the chemically modified agricultural waste. Clean - Soil, Air, Water. 2012;40(2):188-97. doi:10.1002/clen.201100118

7. Chandrappa AK, Biligiri KP. Pervious concrete as a sustainable pavement material - Research findings and future prospects: A state-of-the-art review. Construction and Building Materials. 2016;111:262-74. doi:10.1016/j.conbuildmat.2016.02.054

8. Shershneva MV, Puzanova IE, Soloviova VI. Geoekologicheskii aspekt ispol'zovaniia kal'tsiisoderzhashchikh stroitel'nykh otkhodov [Geoecological aspect of the use of calciumcontaining construction waste]. Proceedings of Petersburg Transport University. 2010;2:286-92. Russian.

9. Shershneva MV. Ispol'zovanie geozashhitnyh svojstv tverdyh othodov na transporte [Use of geoprotective properties of solid waste in transport]. Proceedings of Petersburg Transport University. 2007;3:89-95. Russian.

10. Shershneva MV. Estestvenno-nauchnye osnovy geozashhitnogo rezerva prirodnyh i iskusstvennyh mineralov [Naturalscientific foundations of the geoprotective reserve of natural and artificial minerals]. Proceedings of Petersburg Transport University. 2011;1:237-46. Russian.
11. Navarro-Blasco I, Duran A, Sirera R, Fernández JM, Alvarez JI. Solidification/stabilization of toxic metals in calcium aluminate cement matrices. Journal of Hazardous Materials. 2013;260:89-103. doi:10.1016/j.jhazmat.2013.04.048

12. Svatovskayaa L, Shershneva M, Baydarashvily M, Sychova A, Sychov M, Gravit M. Geoecoprotective properties of cement and concrete against heavy metal ions. Procedia Engineering. 2015;117:345-9. doi:10.1016/j.proeng.2015.08.171

13. Adinarayana KNV, Sasidhar P, Balasubramaniyan V. Modelling of calcium leaching and its influence on radionuclide migration across the concrete engineered barrier in a NSDF. Journal of Environmental Radioactivity. 2013;124:93-100. doi:10.1016/j.jenvrad.2013.04.009

14. Panin AV, Puzanova IE. Geojekologicheskie reshenija obezvrezhivanija ionov tjazhelyh metallov s pomoshh'ju othodov stroitel'noj promyshlennosti [Geoecological solutions for the neutralization of heavy metal ions using waste from the construction industry]. Proceedings of Petersburg Transport University. 2010;2:251-61. Russian.

15. Djegola LA, Simakova YM, Rubleva AV, Nikitina OV, Kuatalieva SB. Model' geokhimicheskogo bar'era dlya akkumulyatsii ionov tyazhelykh toksichnykh I radioaktivnykh metallov [The geochemical barrier model for heavy, toxic and radioactive metals storage]. Estestvennye nauki [Natural Sciences]. 2009;4(29):180-3. Russian.

16. Levit RL, Kudryavtseva VA. Sorption of zinc, cadmium, lead and copper by mineral particulate matter. Regional Ecology. 2015;6(41):52-7. doi:10.30694/1026-5600-2019-1-5-12

17. Azmatova E, Myakisheva A, Tashkinova I. Theoretical and experimental justification of using construction and demolition wastes for disturbed areas rehabilitation. PNRPU Bulletin, Applied ecology. Urban development. 2016;31:110-25. doi: $10.15593 / 2409 ; 5125 / 2016.03 .08$

18. Nevedrov NP, Procenko EP, Balabina IP, Fomina MJu. Tjazhelye metally v pochvah goroda: zagrjaznenie i remediacija [Heavy metals in city soils: pollution and remediation]. Moscow: Ru-Science; 2017. 120 p. Russian. 